\title{
Applications of 1-methylcyclopropene and chitosan lengthened fruit shelf-life and maintained fruit qualities of 'Mutiara' guava fruits
}

\author{
Zulferiyenni ${ }^{1, *}$, Soesiladi Esti Widodo ${ }^{2}$, Yulinda Simatupang ${ }^{2}$ \\ ${ }^{1}$ Agroindustrial Laboratory, Department of Agricultural Product Technology, Faculty of Agriculture, University of Lampung, Bandar \\ Lampung, Indonesia 35145 \\ ${ }^{2}$ Horticultural Postharvest Laboratory, Department of Agrotechnology, Faculty of Agriculture, University of Lampung, Bandar Lampung, \\ Indonesia 35145
}

Emails address:

zulferiyenni@gmail.com (Zulferiyenni), sestiwidodo@gmail.com (S. E. Widodo)

\section{To cite this article:}

Zulferiyenni, Soesiladi Esti Widodo, Yulinda Simatupang. Applications of 1-Methylcyclopropene and Chitosan Lengthened Fruit Shelf-Life and Maintained Fruit Qualities of 'Mutiara' Guava Fruits. Journal of Food and Nutrition Sciences. Special Issue: Food Processing and Food Quality. Vol. 3, No. 1-2, 2015, pp. 148-151. doi: 10.11648/j.jfns.s.2015030102.38

\begin{abstract}
Mutiara' guava fruit is one of two leading guava cultivars sold in Indonesian markets. Its thin skin and climacteric-typed respiration shorten its shelf-life due to high transpiration and respiration rates. Eventhough $2.5 \%$ chitosan was proven to lengthen its shelf-life, the effect of ethylene trapped under chitosan coating needs to be blocked in order to increase its coating affectivity. This research was aimed at studying the effects of 1-methylchyclopropane (1-MCP) and its combination with $2.5 \%$ chitosan on fruit shelf-life and qualities of 'Mutiara' guava. This work was conducted during September-October 2013. A randomized complete block design of two factors was used. The first factor was 1-MCP gassing (control and 1-MCP), and the second one was chitosan (control and 2.5\% chitosan). 1-MCP gas was developed by diluting 0.5 g 1-MCP powder into $30 \mathrm{ml}$ of water. The results showed that 1-MCP as a sole application did not significantly influence fruit shelf-life and qualities through fruit firmness, weight loss, soluble solid, and acidity compared to treatments of control and chitosan alone, but it showed more profound effects in increasing shelf-life and maintaining 'Mutiara' guava fruit qualities when it was applied in a combination with $2.5 \%$ chitosan coating.
\end{abstract}

Keywords: Guava, Coating, 1-MCP, Chitosan, Quality

\section{Introduction}

Among variable cultivars of guava fruits produced in Indonesia, 'Crystal' and 'Mutiara' cultivars lead the freshlyconsumed guava selling in Indonesian markets. Between the two, 'Mutiara' guava fruit is preferred as it has superior characters such as bigger diameter and thicker flesh.

Having a climacteric fruit-typed respiration and thin skin, the qualities of 'Mutiara' guava fruit decline quickly due to high respiration and transpiration rates. To lengthen its shelflife, therefore, it is commonly marketed domestically in a fruit packaging of one layer plastic wrapping. Due to environmental concern, however, a more environmentally friendly fruit coating is preferred than plastic wrapping.

Our previous series of postharvest research dealing with lanzone (Widodo and Zulferiyenni, 2008), bananas and guavas (Zulferiyenni and Widodo, 2010a and 2010b; Widodo et al., 2010 and 2013) concluded that $2.5 \%$ chitosan could be applied as a postharvest fruit coating. However, eventhough fruit ripening was slowed by chitosan, declining fruit firmness occurred continuously during storage (Zulferiyenni and Widodo, 2010a and 2010b; Widodo et al., 2010 and 2013), and it might be due to ethylene trapped inside chitosan coating. To overcome this problem, ethylene effects have to be blocked.

1-methylchyclopropane (1-MCP) is one of anti-ethylene that may be applied to agricultural products. Its special effect is believed to block responses to ethylene so that fruit ripening is hindered (Blankenship and Dole, 2003). 1-MCP applications have been reported to increase the shelf-life of numerous fruits such as kiwifruit (Cantin et al., 2011), apples (Watkins and Nock, 2005), guava (Basseto et al., 2005), papaya (Manenoi et al., 2007), avocado (Jeong et al., 2002), 
banana (Suprayatmi et al., 2005), melon (Guo et al., 2011), and in vegetables such as broccoli (Forney et al., 2003), carrots and lettuce (Fan and Mattheis, 2000), even in ornamentals such as orchids (Raffeiner et al., 2009) and roses (Kongsuwan et al., 2012). To our knowledge, however, there have been no reports on combining both chitosan and 1-MCP as to get their effects synergized.

Therefore, this research objective was to evaluate the effects of 1-MCP alone or in combination with $2.5 \%$ chitosan on fruit shelf-life and qualities of 'Mutiara' guava.

\section{Materials and Methods}

This research was conducted in the Horticultural Postharvest, Department of Agrotechnology, Faculty of Agriculture, University of Lampung during SeptemberOctober 2013. 'Mutiara' guava fruit samples were received directly as a fresh harvest from PT Nusantara Tropical Farm (PT NTF), Way Jepara, East Lampung, Indonesia. The samples were received in pale-yellowing green stadium, wrapped in a one layer of styrofoam net and plastic wrapping as a common fruit packaging applied by PT NTF for domestic market.

Treatments were arranged in $2 \times 2$ factorial design of a randomized complete block design with three replications treated as blocks. First factor was 1-MCP treatment consisting of control (without 1-MCP; M0) and 1-MCP gassing (M1) developed by diluting 0.5 gram $1-\mathrm{MCP}$ in 30 $\mathrm{mL}$ of water. Gassing was applied 24 hours to fruits in a $82 \mathrm{~L}$ of air-tight plastic chamber. The second factor was chitosan coating consisting of control (without chitosan; K0) and $2.5 \%$ chitosan (K1). The chitosan was diluted in $0.5 \%$ acetic acid (Widodo et al., 2010). Treated fruits were then placed in a storing room of room temperature of $28 \pm 1{ }^{\circ} \mathrm{C}$.

Three replications were applied to each experimental unit consisting of one guava fruit. The replications were harvest dates as samples received from PT NTF were not in a single harvest. The variables observed were fruit weight loss, soluble solid content ( ${ }^{\circ}$ Brix), free acidity, and firmness. Variables were observed in every two days up to ten observations, otherwise the treatment was ended when the fruit showed a decrease quality as browning spots and shriveling skin. The data were then graphed with best fitted correlations.

\section{Results and Discussion}

All treated fruits showed increasing weight losses during storage (Figure 1).

The control samples (COM0), however, showed the highest losses compared to others. Samples receiving the treatment combination of chitosan and 1-MCP (C1M1) showed the lowest fruit weight losses during storage. The data in Figure 1 also demonstrated that chitosan applications, whether as a sole application or combination with 1-MCP, were able to decrease fruit weight loss of 'Mutiara' guava fruits. These data proofed that $2.5 \%$ chitosan was effective in preventing transpiration, resulting in lessening fruit weight loss as was also demonstrated in the previous results by Zulferiyenni and Widodo (2010a and 2010b) and Widodo et al. (2010 and 2013).
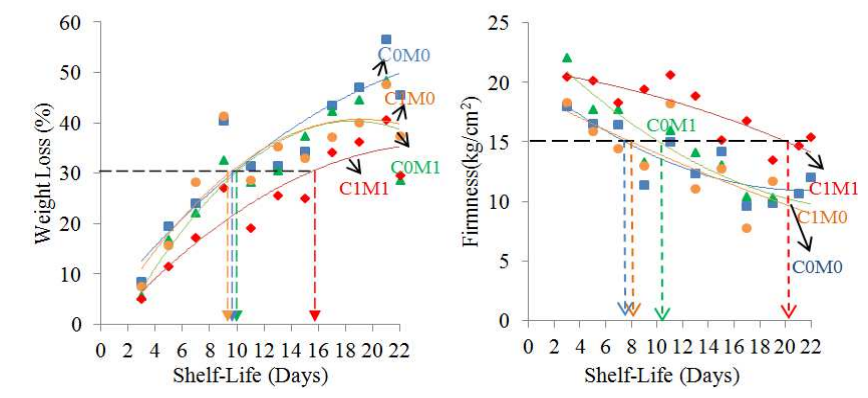

$\mathrm{C} 0=$ without chitosan, $\mathrm{C} 1=2.5 \%$ chitosan, $\mathrm{M} 0=$ without $1-\mathrm{MCP}, \mathrm{M} 1=0.5$ g 1-MCP/30 $\mathrm{mL}$ of water

Figure 1. Changes of fruit weight loss and firmness of 'Mutiara' guava on different treatment combinations of chitosan and 1-MCP during storage.

Generally beginning at about 5 days storage the fruits experienced an increasing fruit weight loss. As illustrated in Figure 1, to reach $30 \%$ fruit weight loss the treatment combination of chitosan and 1-MCP (C1M1) needed about 16 days storage, whereas other treatments needed shorter period of storage at about 9-10 days storage. Throughout storage periods, fruits receiving no treatment (control, C0M0) showed the highest weight loss, chitosan (C1M0) showed lower, 1-MCP (COM1) was much lower, and the treatment combination of chitosan and 1-MCP (C1M1) demonstrated the best in preventing fruit weight loss. The result indicated that 1-MCP application showed more profound effect in lessening fruit weight loss when applied in a combination with chitosan. Effect of 1-MCP in lessening fruit weight loss of guava was also reported by Basseto et al. (2005).

During storage, 'Mutiara' guava fruit firmness decreased regardless of treatments applied (Figure 1) which indicated that fruit ripening progressed during storage. Similar to data of fruit weight loss, fruits receiving treatment combination of chitosan and 1-MCP (C1M1) demonstrated the best in preventing the decrease of fruit firmness, indicating that C1M1 showed the best in slowing fruit ripening. Other treatments were comparably similar in decreasing fruit firmness. However, guava fruits receiving no treatment (control, C0M0) showed a quickly continuing decrease in firmness, and again, it indicated a quick ripening process during storage.

These ripening progresses were easily understood as illustrated in Figure 1. Fruits receiving treatments of chitosan (C1M0), control (C0M0), and 1-MCP (COM1) reached fruit firmness level of $15 \mathrm{~kg} / \mathrm{cm}^{2}$ at 7,8 , and 9 days storage, consecutively, whereas those receiving both treatments (C1M1) reached the same fruit firmness level at about 20 days storage which was much latter period of storage. Again, 1-MCP application showed more profound effect in delaying fruit softening, or slowing ripening, when it was applied in a combination with chitosan. Effect of 1-MCP in delaying fruit softening was also reported by Basseto et al. (2005), Singh 
and Pal (2008), and Porat et al. (2009).

Data of fruit weight loss and firmness in Figure 1 shows that the treatment combination of chitosan and 1-MCP (C1M1) was proven to be the best treatment as it not only slowed transpiration rate resulting in the lowest fruit weight loss, but also slowed the decrease in fruit firmness or slowed fruit ripening. Chitosan played as a fruit coating that not only hindered transpiration resulting in low fruit weight loss, but also hindered $\mathrm{O}_{2}$ consumption resulting in decreasing respiration rate and ethylene production, and consequently increasing fruit shelf-life (Zulferiyenni and Widodo, 2010a and 2010b; Widodo et al., 2010 and 2013). It is understandable, therefore, that the effect of chitosan in increasing fruit shelf-life was more profound when it was applied in a combination with 1-MCP because 1-MCP played as an anti-ethylene and resulted in delaying fruit ripening. Meanwhile, chitosan played as a physical barrier to transpiration resulting in lower fruit weight loss, and to $\mathrm{O}_{2}$ consumption resulting in lower respiration and ethylene production rates. Argenta et al. (2003) and Moretti et al. (2002) reported that 1-MCP delayed fruit softening of pear and tomatoes.
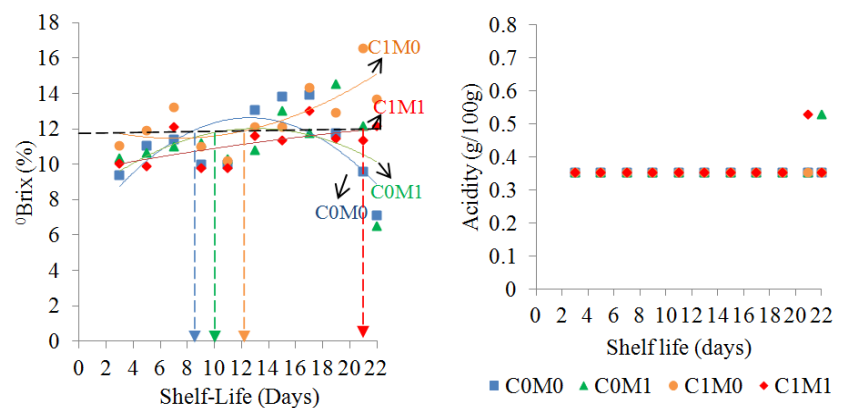

$\mathrm{C} 0=$ without chitosan, $\mathrm{C} 1=2.5 \%$ chitosan, $\mathrm{M} 0=$ without $1-\mathrm{MCP}, \mathrm{M} 1=0.5$ g 1-MCP/30 $\mathrm{mL}$ of water

Figure 2. Changes of soluble solid ('Brix) and acid contents of 'Mutiara' guava fruit on different treatment combinations of chitosan and 1-MCP during storage.

Figure 2 shows that soluble solid contents ( ${ }^{\circ}$ Brix) of 'Mutiara' guava fruit increased during 5-13 days storage. These increases of soluble solid contents correlated with ripening as also indicated with the decrease of fruit firmness (Figure 1). At later days, soluble solid contents of fruits receiving treatments of control (COM0) and 1-MCP (COM1) decreased, except those receiving treatments of chitosan (C1M0) and both treatment combination (C1M1). The decreases indicated that the fruits experienced much further respiration process than the later two treatments, and indicated also much further fruit quality decreases during storage.

Different from fruits receiving other treatments (Figure 2), the soluble solid content $\left({ }^{\circ} \mathrm{Brix}\right)$ of those receiving treatment combination of chitosan and 1-MCP (C1M1) was not decreased but increased in a lower rate than the chitosancoated (C1M0) fruits. Meanwhile, the acidity of 'Mutiara' guava fruits was not affected by all treatments. These might indicated that the treatment combination of chitosan and 1-
MCP (C1M1) caused a much slower ripening process. Phebe and Ong (2010) also reported that 1-MCP did not affect acidity of 'Kampuchea' guava fruit. Widodo et al. (2013) observed that no significant changes of 'Mutiara' guava fruit acidity were occurred during storage.

As shown by Figures 1 and 2, 1-MCP as a sole application did not significantly influence fruit shelf-life and qualities through fruit firmness, weight loss, soluble solid, and acidity compared to treatments of control and chitosan alone, but it showed more profound effects in increasing shelf-life and maintaining guava fruit qualities when it was applied in a combination with $2.5 \%$ chitosan coating. However, the ripening process of 'Mutiara' guava fruit continued during storage as well indicated by the continuing decrease of fruit firmness (Figure 1). This was understood as 1-MCP works only in disturbing response to ethylene (Blankenship and Dole, 2003). This continuously progressed ripening process occurring in 'Mutiara' guava fruits are undesirable not only because of high risk of vitamin $\mathrm{C}$ decrease as the fruits ripe (Widodo and Shiraishi, 1996; Widodo et al., 1996), but also 'Mutiara' guava fruits are consumed as salad guavas, meaning that crispy 'Mutiara' guava fruits are preferred. To stop this ripening process, other anti-ethylene which is capable to stop ethylene production may be applied. Aminoethoxyvinylglycine (AVG) may be a potent antiethylene for guava. Greene and Schupp (2004) and Yildiz et al. (2012) reported that AVG hindered fruit ripening and consequently lengthened fruit shelf-life.

\section{Conclusions}

The results showed that $1-\mathrm{MCP}$ as a sole application did not significantly influence fruit shelf-life and qualities through fruit firmness, weight loss, soluble solid, and acidity compared to treatments of control and chitosan alone, but it showed more profound effects in increasing shelf-life and maintaining 'Mutiara' guava fruit qualities when it was applied in a combination with $2.5 \%$ chitosan coating.

\section{Acknowledgements}

Special thanks are directed to the Directorate General of Higher Education, the Ministry of Education and Culture, the Republic of Indonesia for funding this research through the National Competency Research Grand 2013, to PT Nusantara Tropical Farm (PT NTF), Way Jepara, East Lampung, Indonesia for providing fruit samples, to Dr. Darwin $\mathrm{H}$. Pangaribuan for scientific discussions during manuscript preparation, and to Dr. Cipta Ginting for proof-reading the manuscript.

\section{References}

[1] Argenta, C. L., Fan, X., \& Mattheis, J. P. (2003). Influence of 1-methylcyclopropene on ripening, storage life, and volatile production by d'Anjou cv. pear fruit. J. Agric. Food Chem. 51, 3858-3864. 
[2] Basseto, E., Jacomino. A.P., Pinheiro, A.L., \& Kluge, R.A. (2005). Delay of ripening of 'Pedro Sato' guava with 1methylcyclopropene. Postharvest Biology and Technology, 35, 303-308.

[3] Blankenship, S. M., \& Dole, J. M. (2003). 1Methylcyclopropene: a review. Postharvest Biology and Technology, 28, 1-25.

[4] Cantin, C. M., Holcroft, D., \& Crisosto, C. H. (2011). Postharvest application of 1-methylcyclopropene (1-MCP) extends shelf life of kiwifruit. Actahort., 913, 621-626.

[5] Fan, X., \& Mattheis, J. P. (2000). Reduction of ethyleneinduced physiological disorders of carrots and iceberg lettuce by 1-methylcyclopropene. HortScience, 35(7), 1312-1314.

[6] Forney, C. F., Song, J., Fan, L., Hildebrand, P. D., \& Jordan, M. A. (2003). Ozone and 1-methycyclopropene alter the postharvest quality of broccoli. J. Amer. Soc. Hort. Sci., 128(3), 403-408.

[7] Greene, D.W., \& Schupp, J.R. (2004). Effects of amoniethoxyvinylglycine (AVG) on preharvest fruit drop, fruit quality, and maturation of 'McIntosh' apples. HortScience, 39(5), 1036-1041.

[8] Guo, Q., Cheng, L., Wang, J., Che, F., Zhang, P., \& Wu, B. (2011). Quality characteristics of fresh-cut 'Hami' melon treated with 1-methylcyclopropene. African J. Biotech., 10(79), 18200-18209.

[9] Jeong, J., Huber, D.J., \& Sargent, S.A. (2002). Influence of 1methylcyclopropene (1-MCP) on ripening and cell-wall matrix polysaccharides of avocado (Persea americana) fruit. Postharvest Biology and Technology, 25, 241-256.

[10] Kongsuwan, A., Setha, S., Fuggate, P., \& Naradisorn, M. (2012). Effect of 1-methylcyclopropene (1-MCP) on the postharvest senescence of 'Dallus' rose during storage and its antioxidant system. $1^{\text {st }}$ Mae Fah Luang Univ. Int. Conf. Pp: 17.

[11] Manenoi, A., Bayogan, E.R.V., Thumdee, S., \& Paull, R. E. (2007). Utility of 1-methylcyclopropene as a papaya postharvest treatment. Postharvest Biology and Technology, $44,55-62$.

[12] Moretti, C.L., Araujo, A.L., Marouelli, W.A., \& Silva, W.L.C. (2002). 1-methylcyclopropene delays tomato fruit ripening. Horticultura Brasileira, 20(4), 659-663.

[13] Phebe, D., \& Ong, P. T. (2010). Extending 'Kampuchea' guava shelf-life at $27{ }^{\circ} \mathrm{C}$ using 1-methylcyclopropene. International Food Research Journal, 17, 63-69.

[14] Porat, R., Weiss, B., Zipori, I., \& Dag, A. (2009). Postharvest longevity and responsiveness of guava varieties with distinctive climateric behaviors to 1-methylcyclopropene. HortTechnology, 19(3), 580-585.

[15] Raffeiner, B., Serek, M., \& Winkelmann, T. (2009). 1Methylcyclopropene inhibits ethylene effects in cut inflorescences and potted of Oncidium and Odontoglossum orchid species. Europ. J. Hort. Sci., 74(1), 10-15.

[16] Singh, S.P., \& Pal, R.K. (2008). Response of climacteric-type guava (Psidium guajava L.) to postharvest treatment with 1MCP. Postharvest Biology and Technology, 47(3), 307-314.

[17] Suprayatmi, M., Hariyadi, P., Hasbullah, R., Andarwulan, N., \& Kusbiantoro, B. (2005). Applications of 1methylcyclopropene (1-MCP) and ethylene to control 'Ambon' banana ripening under room temperature. Proceeding of the National Seminar on Postharvest Innovative Technology to Develope Agricultural-based Industry. Faculty of Agriculture Technology, Bogor Agricultural Institute, Bogor, Indonesia 7-8th September 2005. Pp. 253-263. (In Indonesian with English Abstract).

[18] Watkins, C.B., \& Nock, J.F. (2005). Effect of delays between harvest and 1-methylcyclopropane treatment, and temperature during treatment, on ripening of air-stored and controlledatmosphere-stored apples. HortScience, 40(7), 2096-2101.

[19] Widodo, S.E. \& Shiraishi, S. (1996). An initial evaluation on acid citrus hybrids related to 'Lisbon' lemon. Proceedings: International Conference on Tropical Fruits. Vol. I. Kuala Lumpur. Malaysia. 23 -26 July 1996. Pp. 171-176.

[20] Widodo, S.E. \& Zulferiyenni. (2008). Chitosan application on the modified athmospheric packaging of lanzone. The National Seminar of Food 2008: Increasing Food Security Toward Global Markets. A Collaboration of The Indonesian Food Technology Association and the Department of Food and Agricultural Product Technology, Gadjahmada University, Yogyakarta, 17th January 2008. Pp. TP278-TP287. (In Indonesian with English Abstract).

[21] Widodo, S.E., Shiraishi, M., \& Shiraishi, S. (1996). Stable, convenient-working extractants for the determination of Lascorbic acid in citrus extracts. J. Fac. Agr. Kyushu Univ., 41(1\&2), 35-38.

[22] Widodo, S.E., Zulferiyenni, \& Novaliana, D. (2010). Effects of chitosan on the fruit qualities and shelf-life of 'Muli' and 'Cavendish' bananas. In Proc. $3^{\text {rd }}$ National Seminar on Science and Technology, 18-19 October 2010, University of Lampung. Lampung, Indonesia. (In Indonesian with English Abstract)

[23] Widodo, S.E., Zulferiyenni, \& Arista, R. (2013). Coating effect of chitosan and plastic wrapping on the shelf life and qualities of guava cv. 'Mutiara' and 'Crystal'. J.ISSAAS, 19(1), 1-7.

[24] Yildiz, K., Ozturk, B., \& Ozkan, Y. (2012). Effects of aminoethoxyvinylglycine (AVG) on preharvest fruit drop, fruit maturity, and quality of 'Red Chief' apple. Scientia Horticulturae, 144, 121-124.

[25] Zulferiyenni \& Widodo, S.E. (2010a). Technology of passive packaging for chitosan-coated 'Mutiara' guava and 'Muli' banana. Proceeding International Seminar on Horticulture to Support Food Security, Bandar Lampung, Indonesia, 2223rd June 2010. Pp. B36-B43.

[26] Zulferiyenni \& Widodo, S.E. (2010b). Active packaging technologies for chitosan-coated 'Mutiara' guava and 'Muli' banana. Proceeding of the National Seminar on Agroindustrial Applied Technology 2010, Bandar Lampung, Indonesia 5-6th April 2010. Pp. 645-653. (In Indonesian with English Abstract). 